\title{
Malaysian Efforts in Combating IUU Fishing: A Legal and Policy Review*
}

\author{
Farahdilah Ghazali $^{* *} \&$ Wan Izatul Talaat ${ }^{* * *}$ \\ \& Ashraf Rahman ${ }^{* * * *} \&$ Hazmi Rusli****
}

Illegal, unreported and unregulated (IUU) fishing may occur on the high seas or within a national jurisdiction. Several factors were identified as contributing to the occurrence of IUU fishing activities, among which is poor governance marked by limited and overlapping enforcement by related authorities. With very limited regional enforcement bodies and the absence of a regional multilateral agreement, IUU fishing is difficult to overcome. It means that issues relating to overfishing and other fishing conflicts like foreign vessels intrusions and use of illegal fishing methods will continue to be a problem. This paper identifies the Malaysia's legal framework governing IUU fishing, as well as relevant international and regional laws and policies. The paper also discusses the devastating effects of IUU fishing to the global fish stocks and national economy. Although the existing framework is considered comprehensive, it recommends further stringent and fair law enforcement to combat IUU fishing in Malaysia's waters.

\section{Keywords}

Ocean Governance, Sustainability, Biodiversity, Fisheries Crime, Malaysia

* The authors wish to thank the Malaysian Ministry of Education for the Long Term Research Grant granted under the Higher Institution Centre of Excellence funding (Vot 66928). All the websites cited in this article were last visited on November 13, 2019.

** Lecturer at Institute of Oceanography and Environment, Universiti Malaysia Terengganu. The author may be contacted at: farahdilah.g@umt.edu.my/Address: Institute of Oceanography and Environment, University Malaysia Terengganu, 21030 Kuala Nerus, Terengganu, Malaysia.

*** Professor at Institute of Oceanography and Environment, Universiti Malaysia Terengganu. The author may be contacted at: wia@umt.edu.my/Address: Institute of Oceanography and Environment, University Malaysia Terengganu, 21030 Kuala Nerus, Terengganu, Malaysia. Corresponding author.

**** Doctoral candidate at Institute of Oceanography and Environment, Universiti Malaysia Terengganu. The author may be contacted at: ashraf_umt13@yahoo.com/Address: Institute of Oceanography and Environment, University Malaysia Terengganu, 21030 Kuala Nerus, Terengganu, Malaysia.

***** Associate Professor at the Faculty of Syariah and Law, Universiti Sains Islam Malaysia. The author may be contacted at: hazmirusli@usim.edu.my/Address: Faculty of Syariah and Law, Universiti Sains Islam Malaysia, 71800, Bandar Baru Nilai, Negeri Sembilan, Malaysia. 


\section{Introduction}

Illegal, unreported and unregulated ("IUU") fishing is a global issue faced by many coastal countries. It represents a major threat to the long-term sustainability of the world's oceans. IUU fishing undermines national and regional efforts to manage fisheries sustainably and to conserve marine biodiversity. Such fishing is neither a new phenomenon in capture fisheries, nor confined to the high seas. It also occurs in the exclusive economic zones ("EEZs"), which accommodates diverse habitats ${ }^{1}$ and connects both national and foreign vessels to territorial waters. By circumventing regulation by authorities, IUU fishing causes billions of dollars of revenue loss annually to the legitimate fishing industry. As territorial waters are vast and require multiple governing bodies to ensure regulations, owners of IUU fishing vessels are difficult to trace. ${ }^{2}$ With the growing demand for marine resources and the limited marine resources, particularly to support food supply, IUU fishing has become a great threat to fishing countries.

The international fishing communities have been working closely with one another to overcome this issue. However, some countries have limited funding to manage and control fishing activities within their own territorial waters. ${ }^{3}$ These activities can be resilient to international regulatory measures, hiding behind the inability or unwillingness of states to enforce fisheries regulations. ${ }^{4}$ Thus, international cooperation is crucial to resolve this issue effectively. Through regional fisheries management and cooperation, IUU fishing and its related problems can be addressed. Such cooperation would also assist in the implementation of existing initiatives to promote the wellbeing of ecosystems, sustainable tourism, marineresources conservation and food security. ${ }^{5}$ This paper examines IUU fishing in Malaysia to identify international, regional and national measures to resolve

1 K. Riskas, R. Tobin, M. Fuentes \& M. Hamann, Evaluating the Threat of IUU Fishing to Sea Turtles in the Indian Ocean and Southeast Asia Using Expert Elicitation, 217 Biological ConSERVATION 232-9 (2018).

2 J. Azmath \& D. Grewal, A Perspective on Safety and Governance Issues of Fishing Vessels, 31 OCEAN Y.B. 483-5 (2017).

3 G. Petrossian, N. Marteache \& J. Viollaz, Where do "Undocumented" fish land? An empirical assessment of port characteristics for IUU fishing, 21 EuR. J. CRIM. PoL'y Res. 337-51 (2015).

4 D. Miller, N. Slicer \& E. Sabourenkov, An action framework to address illegal, unreported and unregulated (IUU) fishing, 6:2 AustL. J. Mar. \& OCEAN AfF. 78-82 (2014).

5 Supra note 1. It has also been suggested that the determination of the areas of cooperation should follow the biological features as well as the straddling patterns of the fish stocks. See T. Yen Hoang, The South China Sea Arbitral Award: Legal Implications for Fisheries Management and Cooperation in the South China Sea, 6 CAmbridge INT'L L. J. 87-94 (2017). 
Malaysia's problems with this type of fishing.

\section{Principal Factors Contributing to IUU Fishing}

Given that IUU fishing refers to a broad spectrum of fishing activities classified as 'illegal,' 'unreported,' and 'unregulated,' it may occur on the high seas or within national jurisdictions. There are several factors contributing to the occurrence of such fishing activities, one of which is poor governance, referring specifically to the limited and overlapping enforcement by relevant authorities. ${ }^{6}$ Absent regional enforcement bodies or multilateral agreements, IUU fishing is difficult to overcome, and issues relating to overfishing and other fishing problems will continue. ${ }^{7}$

IUU fishing is also triggered by the high and growing demand for seafood, particularly in Southeast Asia, where the populations profoundly depend on marine resources for food and income. ${ }^{8}$ IUU fishing is highly profitable simply because it is more 'expensive' to be a responsible fisher in the market. As such fishing is unreported and unregulated, it provides lucrative revenue with no imposed tax. IUU fishing also occurs on such a large scale because it can often be practised with impunity. This is mainly the case in the territorial waters or EEZs of countries that cannot afford to implement costly and complex fisheries control measures. The complexity of the fishing industry and the many levels of organisation involved in this industry leave it vulnerable to the influence of organised transnational crime and corruption.

\section{Major Impacts of IUU Fishing}

IUU fishing may result from the fact that many countries have yet to adopt adequate frameworks for fishing management at the national level. Overfishing is one of the principal effects of IUU fishing. According to the UN Food and

6 Id. See also Dirhamsyah, IUU Fishing in Indonesia's Live Reef Fisheries, 4 Austl. J. Mar. \& Ocean Aff. 44-52 (2012).

7 Z. Hongzhou, Fisheries Cooperation in the South China Sea: Evaluating the Options, 89 MAR. PoL'y 67-76 (2018).

8 M. Johns, Enhancing Responsible Fishing Practices in South East Asia to Combat Illegal, Unreported and Unregulated (IUU) Fishing, 5 Austl. J. Mar. \& Ocean Aff. 112-9 (2013). 
Agricultural Organization ("FAO"), up to thirty percent of the global catches may be caught illegally or remain unreported. ${ }^{9}$ Unreported catches make sustainable fisheries unworkable and threaten all conservation measures. IUU fishing targets already depleting stock and juveniles, or occurs in areas that are closed to fishing. ${ }^{10}$ Overfishing is greatly enabled by the existence of foreign vessels equipped with sophisticated technologies. Malaysia and Indonesia have been severely affected economically by the overfishing by such technologies. ${ }^{11}$ Therefore, such activities can also be considered economic crime. ${ }^{12}$

The second major effect of IUU fishing is that of bycatch, which is also associated with the presence of large vessels equipped with sophisticated technologies. ${ }^{13}$ Bycatch is not limited to commonly fished species or fish of unfavourable sizes, but may also include whales, dolphins, seabirds, turtles, sharks, rays and other forms of marine wildlife. ${ }^{14}$ The use of banned and destructive fishing gear such as trawls, bombs and cyanide devastates sea floors, and reefs leads to even greater amounts of bycatch, as well as interrupting marine biodiversity. ${ }^{15}$ Thus, investing in programmes to tackle IUU fishing can help to resolve issues such as turtle extinction and other consequences of bycatch. ${ }^{16}$

The third major effect of IUU fishing is the severe economic loss and social damage inflicted on coastal communities and small-scale fisheries. ${ }^{17}$ This economic loss is a result of overfishing leading to depleting fish stocks and marine biodiversity, as well as creating significant collateral damage to marine ecosystems. ${ }^{18}$ IUU fishing constitutes more than a crime against fish because the documented crimes other than fisheries crimes associated with IUU fishing (e.g., document forgery, human trafficking for labour, smuggling, money laundering, and drugs trafficking) clearly fall within the definition of transnational criminal activities according to this classification system. It has actually demonstrated that one crime is vital for the

9 NIC, Global Implications of Illegal, Unreported, and Unregulated (IUU) Fishing (Sept. 19, 2016), available at https:// fas.org/irp/nic/fishing.pdf.

10 D. Agnew et al., Estimating the Worldwide Extent of Illegal Fishing, 4:2 Plos One 1-3 (2009).

11 R. Pedrason, Y. Kurniawan \& Purwasandi, Handling of Illegal, Unreported and Unregulated (IUU) Fishing, 2:1 J. Pertahanan 71-90 (2016).

12 S. Nova, Illegal, Unreported and Unregulated Fishing: The Impacts and Policy for its completion in coastal West of Sumatera, 2 Indon. J. InT'L L. 237-50 (2017).

13 Supra note 12.

14 M. Hall et al., Mitigating bycatch in tuna fisheries, 27 Rev. Fish BIOLOGY \& Fisheries 881-908 (2017).

15 Supra note 12.

16 Supra note 1.

17 Supra note 11.

18 Id. See also supra notes 3 \& 10. 
other to flourish. ${ }^{19}$ The complexity of the maritime-security breaches does not allow for each illegal activity to be understood, addressed and suppressed individually. In addition, IUU fishing not only causes fisheries disputes and maritime incidents involving fishers, but also poses serious threats to maritime security and stability. Thus, a comprehensive and inclusive approach is needed to explore, understand and disrupt the linking and overlapping of various maritime-security breaches. ${ }^{20}$

\section{IUU Fishing in Malaysia}

The ocean plays a very important role in the development of marine-related economic activities, including oil and gas exploration, sea transport services and fisheries. Malaysia has to a certain extent adopted a comprehensive monitoring, control and surveillance ("MCS") system its EEZ, which was founded based on the United Nations Convention on the Law of the Sea 1982 ("UNCLOS"). Malaysia has also adopted various pre-emptive mechanisms to prevent the exploitation of marine resources, which focus on the west coast of the Malaysian Peninsular. ${ }^{21}$ Being a fisheries nation, Malaysia is facing serious and worsening problems in fisheries management. Its problems with IUU fishing are generally associated with encroaching fishers from neighbouring countries such as Vietnam, Thailand and Indonesia. $^{22}$

Approximately 980,000 metric tonnes of fish (worth RM6 billion) are said to be stolen at Malaysian waters (mainly East Coast) annually by illegal foreign vessels usually from Thailand, Vietnam and Indonesian..$^{23}$ It has been roughly estimated that only 50 percent of the fish caught in Malaysian waters are landed; the rest are 'unreported' mainly because of territorial sea encroachment by foreign fishing vessels. ${ }^{24}$ On the East Coast of the Malaysian Peninsular, encroachment of foreign

19 M. Noonan \& E. Williams, Combating Maritime Transnational Crime: An Australian Perspective, 12:1 J. INDIAN OCEAN REGION 46-51 (2016).

20 I. Chapsos \& S. Hamilton. Illegal Fishing and Fisheries Crime as a Transnational Organized Crime in Indonesia, 22 Trends in Organized Crime 1-19 (2018).

21 A. Saharuddin, National Ocean Policy. New Opportunities for Malaysian Ocean Development 25:6 MarInE POL'y 42736 (2001).

22 Supra note 12.

23 N. Majid, Malaysia loses RM6b annually due to illegal fishing in South China Sea, New STRAIt TimES, June 19, 2017, available at https://www.nst.com.my/news/nation/2017/06/250427/malaysia-loses-rm6b-annually-due-illegal-fishingsouth-china-sea.

24 A. David, Illegal foreign fishermen affecting livelihood of KT fishermen, NEw STRAIT TIMES, Dec. 14, 2017, available at 
fishers not only affects the livelihood of the local fishers, but also causes destruction to marine biodiversity, as well as being entangled with drugs and firearms trafficking. ${ }^{25}$

\section{Combatting IUU Fishing: International and Regional Efforts}

The global community is trying to address the underlying weaknesses of the regulatory regime, threats to marine biodiversity and the revenue losses of fisheries nations, which leads to the re-examination of the international regulatory framework for fisheries in many countries. Pomeroy et al. have proposed several strategies to improve the sustainability of fishery resources, including strengthening transboundary or regional fisheries management, engaging the private fisheries sector, implementing an ecosystem-based approach to fisheries management ("EAFM"), and enforcing a market-based approach. ${ }^{26}$ Some countries, including Australia and Malaysia, have advanced efforts at the national level by reinforcing their domestic legal frameworks, while the EU has proposed stricter measures to limit trade in IUU fish. ${ }^{27}$

The importance of monitoring and regulatory enforcement for both fishing activities and trade should never be ignored when combatting IUU fishing. ${ }^{28}$ In addition, effective coordination between government agencies, data and research management, and participation and commitment by all stakeholders are essential for mitigating IUU fishing. ${ }^{29}$ Such cooperation requires an effective governance framework that includes regulation, enforcement, coordination and participation that involves multiple stakeholders.

https:/www.nst.com.my/news/nation/2017/12/314349/ illegal-foreign-fishermen-affecting-livelihood-kt-fishermen.

25 Id.

26 R. Pomeroy et al., Improving Marine Fisheries Management in Southeast Asia: Results of A Regional Fisheries Stakeholder Analysis, 65 Marine Pol'y 20-9 (2016).

27 Supra note 11.

28 Supra note 4.

29 Supra note 7. 
Table 1: International Instruments to Combat IUU Fishing

\begin{tabular}{|l|l|}
\hline \multicolumn{1}{|c|}{ UN } & \multicolumn{1}{c|}{ FAO } \\
\hline UNCLOS 1982 & $\begin{array}{l}\text { FAO Agreement to Promote Compliance with International } \\
\text { Conservation and Management Measures by Fishing Vessels } \\
\text { on the High Seas, 1993 }\end{array}$ \\
\hline $\begin{array}{l}\text { United Nations Fish } \\
\text { Stocks Agreement, 1995 }\end{array}$ & $\begin{array}{l}\text { International Plan of Action to Prevent, Deter and Eliminate } \\
\text { Illegal, Unreported and Unregulated Fishing, 2001 (IPOA- } \\
\text { IUU) }\end{array}$ \\
\hline & $\begin{array}{l}\text { FAO Agreement on Port State Measures to Prevent, Deter } \\
\text { and Eliminate IUU Fishing, 2009 }\end{array}$ \\
\hline
\end{tabular}

Compiled by the authors.

Among the earliest multilateral action taken by the international community to alleviate problems relating to ocean governance were the United Nations Convention on the Law of the Sea I (1958) and II (1960). Given that these two conventions failed to address issues about territorial limits and fisheries rights, the UNCLOS was further negotiated and signed in 1982 to define the rights and responsibilities of nations with respect to their use of the world's oceans, and to establish guidelines for businesses, environment and management of marine natural resources. Following the measures stipulated in the UNCLOS, several legal instruments have been created (Table 1).

The FAO Agreement to Promote Compliance with International Conservation and Management Measures by Fishing Vessels on the High Seas 1993 prevents the 're-flagging' of vessels fishing on the high seas under flags of states that are unable or unwilling to enforce international fisheries conservation and management measures. ${ }^{30}$ The maintenance of records of fishing vessels are covered extensively by the provisions of this agreement. ${ }^{31}$ The United Nations Fish Stocks Agreement 1995 ensures the long-term conservation and sustainable use of straddling and highly migratory fish stocks within the framework of the UNCLOS. ${ }^{32}$ This Agreement spells out the duties of flag states, including those related to registration and records of vessels, authorisations, MCS, as well as compliance and enforcement. Cooperation in international, regional and sub-regional enforcement is also addressed in the

30 FAO, Agreement to Promote Compliance with International Conservation and Management Measures by Fishing Vessels on the High Seas 1995, available at $\mathrm{http} / /$ www.fao.org/3/X3130m/X3130E00.HTM.

31 Id.

32 A. Tahindro, Sustainable Fisheries: The Legal Regime of the 1995 United Nations Fish Stocks Agreement and Its Contribution to Subsequent Developments Promoting Sustainable Fisheries, Legal Order IN THE World's OcEANs 32369 (M. Nordquist et al. eds., 2017). 
agreement, along with boarding and inspection procedures and port state measures. ${ }^{33}$

In addition, several international plan of actions ("IPOAs") have been introduced to address specific issues in fisheries governance, including the International Plan of Action to Prevent, Deter and Eliminate Illegal, Unreported and Unregulated Fishing 2001 ("IPOA-IUU"). This IPOA serves as an international tool to combat IUU fishing, used by all states in general, flag states, coastal states, market states, port states and regional fisheries management organisations ("RFMOs"). ${ }^{34}$ The IPOA-IUU calls on all countries to develop and implement a consistent NPOA, and to review it periodically. The core elements of the IPOA-IUU are the implementation of the responsibilities relating to fisheries of flag states, coastal states and port states, as well as the introduction of market-based measures. ${ }^{35}$

The FAO Agreement on Port State Measures to Prevent, Deter and Eliminate IUU Fishing 2009 was signed to prevent vessels engaged in IUU fishing from using ports and landing their catches. This Agreement aims to reduce the incentive of such vessels to continue operating and to block fishery products of IUU fishing from reaching national and international markets. It also covers the role of flag states and RFMOs in the implementation of port state measures. ${ }^{36}$

Although many international instruments have underlined the principles of responsible fisheries for coastal states to regulate matters in relation to sustainable marine-resources management, it is also important to ensure that comprehensive regional fisheries management considers the measures to protect marine ecosystems at the regional level. Through regional efforts, several measures can be adopted such as preventive actions against the adverse effects of IUU fishing on marine ecosystems and the sustainability of fishing industries (Table 2).

33 The 1995 Agreement for the Implementation of the Provisions of the United Nations Convention on the Law of the Sea of 10 December 1982 relating to the Conservation and Management of Straddling Fish Stocks and Highly Migratory Fish Stocks, U.N. Doc. A/CONF.164/CRP.8 (Aug. 2, 1995), available at https://www.un.org/Depts/los/fish_stocks_ conference/fish_stocks_conference.htm\#Agreement.

34 FAO, Illegal, unreported and unregulated fishing (2016), available at $\mathrm{http}: / / w w w . f a o . o r g / 3 / a-i 6069 e . p d f$.

35 FAO, International Plan of Action to prevent, deter and eliminate illegal, unreported and unregulated fishing. Rome (2001), available at http://www.fao.org/3/a-y1224e.pdf.

36 Agreement on Port State Measures to Prevent, Deter and Eliminate Illegal, Unreported and Unregulated Fishing, 55 I.L.M. 1157-1798 (2016). 
Table 2: Regional Instruments to Combat IUU Fishing

\begin{tabular}{|l|l|l|}
\hline \multicolumn{1}{|c|}{ SEAFDEC } & \multicolumn{1}{|c|}{ ASEAN } & \multicolumn{1}{|c|}{ CTI-CFF } \\
\hline $\begin{array}{l}\text { SEAFDEC Regional } \\
\text { Fishing Vessels Record } \\
\text { (RFVR) }\end{array}$ & $\begin{array}{l}\text { ASEAN Guidelines for Preventing the } \\
\text { Entry of Fish and Fishery Products from } \\
\text { IUU Fishing Activities into the Supply } \\
\text { Chain }\end{array}$ & $\begin{array}{l}\text { CTI-CFF Regional } \\
\text { Plan of Action } \\
\text { (RPOA) }\end{array}$ \\
\hline & $\begin{array}{l}\text { ASEAN Catch Documentation } \\
\text { Scheme (ACDS) }\end{array}$ & \\
\hline
\end{tabular}

Compiled by the authors.

One significant measure taken by the Association of Southeast Asian Nations ("ASEAN") members through the Southeast Asian Fisheries Development Centre ("SEAFDEC") is the Regional Fishing Vessels Record ("RFVR"). This measure aims to develop a regional record of fishing vessels, beginning with vessels measuring 24 metres in length (which could be expanded later with the recording of vessels measuring fewer than 24 metres) and is applicable to countries in the region attempting to improve their fishing licensing systems which conform to regional and international requirements. The refined fishing licensing systems and the RFVR could be used effectively as a fisheries management tools for combatting IUU fishing in Southeast Asia. ${ }^{37}$

Another substantive regional effort was to create the ASEAN Guidelines for Preventing the Entry of Fish and Fishery Products from IUU Fishing Activities into the Supply Chain. It was introduced to provide tools for the ASEAN Member States ("AMS") to ensure that fish and fisheries products from the region entering the global supply chain do not come from IUU fishing activities. The objectives of the guidelines are to: ${ }^{38}$

1. introduce strategies and recommend appropriate measures for the AMS in order to prevent the entry of IUU and fisheries products into the supply chain;

2. provide guidance for the AMS to develop, strengthen and implement effective fisheries management for responsible and sustainable fisheries; and

3. promote regional collaboration among the AMS to strengthen MCS systems of fish and fisheries products entering the supply chain. 
The ASEAN Catch Documentation Scheme ("ACDS") was also introduced in accordance with the requirement of SEAFDEC Member Countries to comply with the requirements of the EC Regulation 1005/2008. The objectives of the scheme are to: ${ }^{39}$

1. provide a unified framework that will enhance traceability of fish and fisheries products for effective marine fisheries management in AMS;

2. enhance the credibility of fish and fisheries products for intra-regional and international trade; and

3. prevent entry of fish and fisheries products attained from IUU fishing activities into the supply chain of AMS.

In addition, through a multilateral partnership, the Coral Triangle Initiative on Coral Reefs, Fisheries, and Food Security ("CTI-CFF") has successfully implemented its Regional Plan of Action ("RPOA") aiming to sustain marine and coastal resources. The RPOA is guided by nine principles designed to promote responsible fishing practices, including combatting IUU fishing, in the region. This action plan was agreed to by the fisheries ministers of six countries in May 2007. Among the goals and targets relating to combatting IUU fishing are Goal 2 through EAFM and Goal 5 through Threatened Species Status Improving ("TSSI"). The following three targets are stipulated under Goal 2: ${ }^{40}$

1. criminalisation and enforcement to combat IUU fishing as "transnational organised crime";

2. improved enforcement of IUU fishing through greater collaboration; and

3. new surveillance, enforcement and judicial cooperation measures to address IUU fishing.

The targets enumerated under Goal 5 are two-pronged: ${ }^{41}$

1. enforcement of legislation and action on shark fishing, including reducing incidence of IUU catch; and

2. recognition and enforcement of laws and regulations to combat IUU fishing and trafficking of threatened marine species as transnational organised crime.

39 SEAFDEC, ASEAN Catch Documentation Scheme for Marine Capture Fisheries (Sept. 28, 2019), available at https:// asean.org/wp-content/uploads/2012/05/16.-ASEAN-Catch-Documentation-Scheme.pdf.

40 CTI-CFF, RPOA (CTI-CFF Regional Plan of Action), available at http://coraltriangleinitiative.org/rpoa.

$41 \quad I d$. 
RPOA has faced many challenges, which demonstrates the need for ongoing commitment by participating states. RPOA measures may be able to stop the increasing IUU fishing, particularly in Southeast Asia. Thus, the development of a system to detect IUU vessels, as well as regional cooperation and collaboration are essential to combat the growing IUU fishing in national waters. ${ }^{42}$ Regional cooperation in the fisheries sector will ultimately assist to meet the needs to provide food security and economic development, to create a sustainable fisheries sector, and to prevent maritime conflict. ${ }^{43}$

\section{Combatting IUU Fishing in Malaysia: Domestic Legal Framework}

IUU fishing is jeopardising the Malaysian fish harvest, as well as the long-term survival of Malaysia's fishing industries and the livelihood of its coastal communities, particularly on the East Coast of Malaysia. IUU fishing has damaging effects on the fish stocks and marine habitat created by the use of illegal fishing gear. ${ }^{44}$ Malaysia has passed several pieces of legislation to control IUU fishing in Malaysian waters. Notably, the law-making power in Malaysia is divided between federal and state governments, as enumerated under the Ninth Schedule of the Federal Constitution, which was divided into three lists. Matters pertaining to land management include coastal areas, which fall under the states' jurisdictions, while the federal government has authority over matters pertaining to the sea and marine resources, including fisheries in coastal areas. By virtue of that list, the federal government of Malaysia passed the Fisheries Act 1985 in order to govern matters relating to fisheries, including the conservation, management and development of maritime and estuarine fishing and fisheries.

The Fisheries Act 1985 had undergone several amendments till 2012, to strengthen governance in Malaysian waters. This legislation provides regulatory and

42 Supra note 10. Looking at the regional cooperation between Thailand and Malaysia, regional cooperation can be further extended through information sharing system to accomplish a mutual maritime-security objective.

43 C. Bellmann et al., Global trade in fish and fishery products: An overview, 69 MARINE PoL'y 181-8 (2016).

44 Z. Zakariah, Illegal, unreported and unregulated fishing (IUU) in Malaysian waters, MIMA (2004), available at http://www.mima.gov.my/component/category/10-presentation-repository. See also APEC, Case Study on Illegal, Unreported and Unregulated (IUU) Fishing off the East Coast of Peninsular Malaysia (Oct. 2008), available at file:/// C:/Users/user/AppData/Local/Microsoft/Windows/INetCache/IE/7VJQZEFJ/08_fwg_IUU_fishing_east_coast_ Peninsular_Msia.pdf. 
enforcement measures to combat unauthorised marine-related activities, particularly illegal maritime encroachment by foreign fishing vessels in Malaysia's territorial waters. Section 6 of the Act empowers the Director General of Fisheries to make plans to regulate matters of IUU fishing in Malaysia in accordance with the NPOA-IUU. Given that IUU may also involve local fishers or vessels, Section 8 stipulates that any fishing activity in Malaysia's fisheries waters requires a valid licence issued, and that the vessel shall not contravene any condition in the licence issued. With respect to foreign fishing vessels, Part V of the Fisheries Act 1985 spells out their rights and duties to access fisheries resources in Malaysian fisheries waters. ${ }^{45}$ Section 15 prohibits any fisheries activity by foreign fishing vessels unless authorised under an international fisheries agreement between Malaysia and other state or international organisation under which the vessel is flagged. ${ }^{46}$ However, the operation of such vessel shall require permit under Section 19 and to comply fishing regulation as embedded in Section 17.

The Fisheries Act 1985 provides details on the prohibited fishing methods under Section 26, including the use of explosives, poisons or pollutants, or electrical equipment, or any prohibited gear. Further, no person is allowed to fish, disturb, harass, catch or take any aquatic mammal or turtle beyond the national jurisdiction; any aquatic mammal or turtle caught should be released instantly. ${ }^{47}$ To ensure compliance with the rules and regulations, Section 46 prescribes measures to be taken where any authorised officer may act without warrant if they believe there is a violation. This provision allows an authorised officer to halt and search any vessel or vehicle transporting fish, and further to inspect all the documents and anything else on board, including the crew, equipment and the catch. ${ }^{48}$

The enactment, amendment and enforcement of the Fisheries Act 1985 reflects Malaysia's commitment to enhancing its local fisheries sector, as well as to ensuring its compatibility with international legal requirements and management practices. This Act has well translated the state's obligations as enumerated under the UNCLOS. Malaysia also has several other pieces of federal legislation that

45 Fisheries Act 1985 (Act 317), §§ 15-24.

46 The Indonesian Government has campaigned for illegal fishing to be recognised as a transnational organised crime in order to promote more effectively regional control mechanism on IUU Fishing. See A. Yuliantiningsih et al., From Illegal, Unreported and Unregulated Fishing to Transnational Organised Crime in Fishery from an Indonesian Perspective, 11 J. EAST AsIa \& INT'L L. 335-58 (2018).

47 Fisheries Act 1985 (Act 317), § 27.

48 Section 47 of the Fisheries Act 1985 allows authorized officer to entry, seizure and arrest without a warrant when he has reason to believe that an offence has been committed under the Fisheries Act 1985. Section 47A, Section 47B and Section $47 \mathrm{C}$ authorize any fisheries officer to investigate, to require attendance of witnesses and to examine witnesses. 
help to strengthen and complement the implementation of the Fisheries Act 1985, particularly those related to fisheries management and enforcement in the EEZ. These laws are specified in the Exclusive Economic Zone Act 1984, the Continental Shelf Act 1966, the Territorial Sea Act 2012, and the Maritime Enforcement Agency Act 2004, which are also essential in governing maritime-related activities and resources in Malaysia's EEZ. The first three Acts were enacted to define national jurisdiction and sovereign rights in the maritime space, while the fourth Act was adopted to establish the Malaysian Maritime Enforcement Agency, which is the national coast guard.

\section{Conclusion}

The international conventions have formed a solid legal foundation for fisheries governance in the national EEZs and the high seas. These international fisheries instruments are ideal for promoting sustainable and responsible fisheries practices at the international and regional levels. Nonetheless, measures, regulations, strategies and efforts to deter, prevent and eliminate IUU fishing at the national, regional and international levels can only be achieved through national and international commitments as well as effective actions at these levels. ${ }^{49}$ However, these measures must be fully implemented and regularly revised for effective execution.

Apart from commitment from government and other stakeholders in the fisheries sector, public participation is essential to combat this increasing problem. There must be public-awareness campaigns for clear communication that IUU is a crime which affects everybody. Alerting authorities on known illegal fishing activities may facilitate in combatting IUU fishing. In addition, more holistic and proactive fisheries management should be adopted to safeguard the marine environment and its natural resources. The national fisheries authorities should also able to incorporate more viable conservation policies and action plans in governing fisheries activities by considering other domestic factors such as the livelihood of the local communities, ocean governance systems, and the biological and ecological features of the marine biodiversity in the area.

Nonetheless, it can be surmised that the Malaysian fisheries governing framework has significantly improved over the years through national efforts with substantial financial and regional support and commitment. These efforts have been reflected in

49 Despite the United Nations Conventions as Transnational Crimes 2008 (UNTOC), states rarely used UNTOC in fishery sector. See Yuliantiningsih et al., supra note 46. 
actions taken by Malaysia's Department of Fisheries to combat IUU fishing through the termination of the licences of 472 deep-sea vessels that were violating the Fisheries Act 1985 and the subsidiary laws ${ }^{50}$ The Automatic Identification System has been installed on 2,630 trawlers of Zone B. Also, regional cooperation to combat illegal fishing has also been strengthened between the ASEAN countries. ${ }^{51}$ This has proven that apart from having a regulatory framework to address IUU fishing in Malaysia, an effective institutional framework and enforcement agencies are vital to implement and coordinate such measures and to ensure responsible fishing practices, among not only the local stakeholders, but also their regional counterparts.

50 A. Abas, Fisheries Department doing all it can to manage, protect Malaysia's maritime resources, says DG, NEW Strait Times, Nov. 8, 2017, available at https://www.nst.com.my/news/nation/2017/11/300933/fisheries-departmentdoing-all-it-can-manage-protect-malaysias-maritime.

51 D. Chan, Fishing trawlers to be fitted with AIS system to settle accusations of encroachment, NEw StRAIT TIMES, June 11, 2016, available at https:/www.nst.com.my/news/2016/06/151269/fishing-trawlers-be-fitted-ais-system-settleaccusations-encroachment-video. 